\title{
Ernő Foerk and Gyula SÁndy's Tüköry Mansion in Dioš, Croatia: Genealogy of Architectural and Stylistic Features
}

\author{
Boris Dundović \\ Institute of Art History, Zagreb, Croatia \\ boris.dundovic@gmail.com
}

\begin{abstract}
Tüköry Mansion in Dioš (Diósszentpál), Croatia, was designed by architects Ernő Foerk and Gyula Sándy in 1904. It is situated near the Central Slavonian town of Končanica and in close proximity of Daruvar, on an estate that belonged to Tüköry family. The late-historicist country house was commissioned by Paula von Falkenberg, a widow of Alajos Tüköry de Algyest, as a permanent residence for her and her three children. It was built in the eclectic late-historicist style of fin-de-siècle Hungary, highly inspired by the late-mediaeval art and architecture of northern Italy. Those stylistic influences were strongly manifested in the architectural design of the mansion, but even more its great hall, the focal point of its layout, designed in 1904-05. Based on both archival and terrain research, this paper aims to determine the main factors of cultural and architectural identity of the mansion by elucidating its history and stylistic genealogy.
\end{abstract}

Keywords: Daruvar, manor house, cultural history, late-historicist eclecticism, mediaeval motifs, great hall

\section{INTRODUCTION}

Tüköry Mansion in Dioš (Hun. Diósszentpál) is a rare example of Hungarian country house building from the beginning of the $20^{\text {th }}$ century on the territory of Croatia. The late-historicist country house, adorned with elements from turn-of-the-century Hungarian stylistic tendencies, was built in 1904 according to designs by Ernő Foerk and Gyula Sándy, architects and professors from Budapest. It was the managerial centre of the estate

of Paula von Falkenberg (1868-1949), daughter of the Prince of the German county of SaynWittgenstein-Sayn and widow of Alajos Tüköry de Algyest. The mansion was planned as a grand house set in an arcadian environment. Located on a plateau above the fishponds along the Ilova River, the architecture of the castle-like mansion blends harmoniously with the hilly and forested bucolic landscape of Končanica and Daruvar.

The architecturally elaborate Tüköry Mansion (Figure 1) is a detached building with an intricate spatial syntax and layout mechanism, enriched with sophisticated technical solutions, such as the modern load-bearing system and an imposing roof structure. The main residential part is composed of a two storey high great hall, connected both to the daytime living area of the ground floor and to the bedrooms on the upper floor. 
The adjacent servants' wing spreads to the west from the residential area. The architectural equipment of the interior, its rich wall paintings, and stained glass in the central hall were all patterned upon the modern craftsmanship and Gesamtkunstwerk [1] tendencies ofthe period.

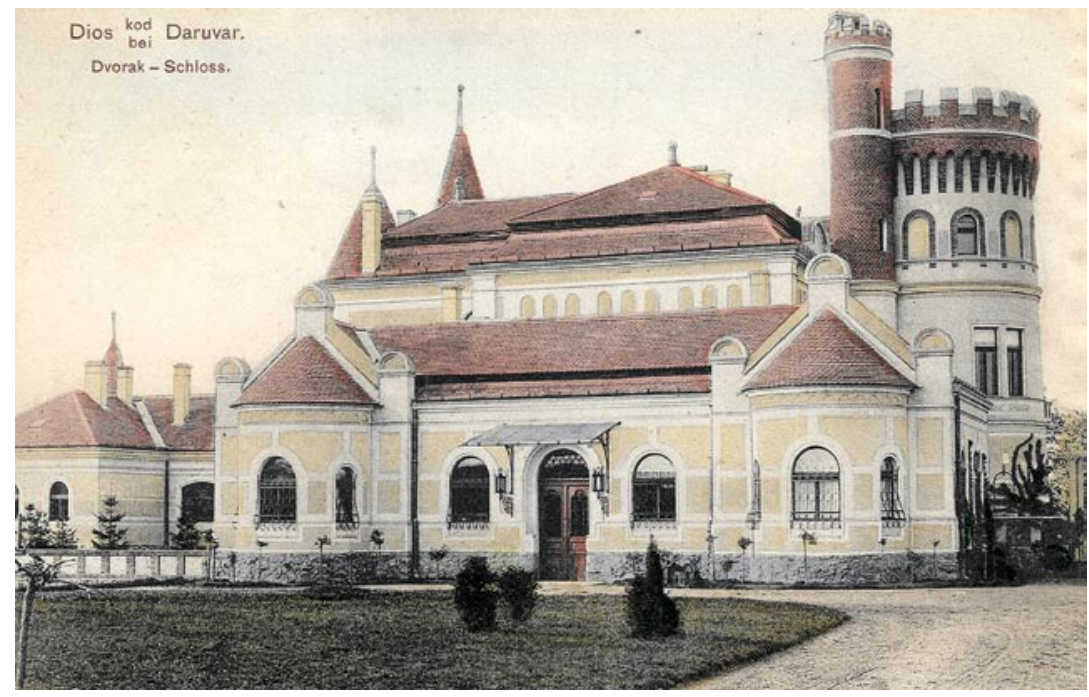

Figure 1. Tüköry Mansion in Dioš around 1910, view from the south [2]

As is the case with most of the Croatian country houses in the twentieth century, Tüköry Mansion lost most of its wider estate and was fated to inadequate use and poor management, which resulted in a menacingly poor condition of the building, calling for urgent action. By the beginning of the $21^{\text {st }}$ century, the architectural and cultural history of the mansion was long forgotten, and its connections to Hungarian fin-de-siècle architects and their tendencies were left unexplored. However, based on the authors' research conducted from 2014 to 2018, the Croatian Conservation Institute completed the interdisciplinary study on the architectural and cultural history of Tüköry Mansion, as well as detailed architectural survey of its existing state [3]. These activities were carried out in accordance with the established methods of built heritage documentation and provided the valorisation and guidelines to the concluding presentation of the mansion, regardless of the purpose or user it may serve in the future. Yet, even with the completion of all preparatory work, the reconstruction and restoration work have not been undertaken, as the mansion still waits for a suitable investor.

This paper presents an overview of the comprehensive research of architectural and stylistic features of Tüköry Mansion. These features resulted from the remarkable symbiotic combination of Ernő Foerk and Gyula Sándy’s architectural and artistic languages, enriched with valuable input of the mansion's commissioner Paula von Falkenberg. This paper aims to focus on the visual and spatial language of the mansion, and to highlight the mechanisms through which those elements work together to write its architectural and artistic narrative.

\section{CULTURAL SETTING AND FACTORS OF IDENTITY}

Dioš is a village that has culturally and historically gravitated towards the town of Daruvar, an urban focal point of Central Slavonia. In ancient times, Daruvar was a Roman settlement founded on thermal springs and called Aquae Balissae. It was a part of the municipium Iasorum, an area with predominantly Illyrian population. 
However, the original ancient historical layer of the town was obscured by centuries of mediaeval oblivion, and it only resurfaced in the mid-eighteenth century with the Janković family, when the wider area became their seigniorial estate.

At that time, the Roman layer of Daruvar (former market-town of Podborje) started to reemerge in the form of numerous archaeological findings. In the $19^{\text {th }}$ century, when antiquity and archaeology gained a lot of scientific interest, those findings drew many archaeologists' attention to Central Slavonia. While many archaeological artefacts discovered in the area were sent to various museums and other scientific institutions, several of them even ended up as built-in interior decoration of the Janković Manor in Daruvar, a grand country house built by count Antun Janković from 1771 to 1777 [4].

In the course of history, Janković family established a strong historical and cultural presence both in Hungary and Croatia. Their many estates were located from Balaton Lake in the north to the river Sava in the south. They had a great impact on the cultural, economic and social development of the region, regardless of present-day borders, and their contribution to the industrial, traffic and urban development of the region is evident even today. One merely needs to glance at the map of the Austro-Hungarian railway system to notice that in the $19^{\text {th }}$ century, Daruvar became an intensively functional urban node, strongly connecting its entire rural area to Budapest [5]. Jankovićs resided in Daruvar until 1879, when count Julije Janković sold the whole estate to Magdolna Lechner, a Hungarian widow. Her daughter Antónia Lechner married Sándor Tüköry de Algyest, a nobleman from Budapest. Starting with him, the dynasty of Tükörys managed Central Slavonian estates for the next four decades [6].

During the last two decades of the $19^{\text {th }}$ century, the Tüköry family continued the intensive economic and cultural development of Daruvar and its surrounding area. One of the most active members of the family was Alajos Tüköry (1854-1903), son of Sándor and Antónia, who was several times elected as a representative in the Croatian Parliament in Zagreb [7]. In 1888, he married Paula von Falkenberg - unlawful daughter of the German Prince of SaynWittgenstein-Sayn - with whom he had four children: Pál (died being only four years of age), Melitta, Boris, and Lívia. After Alajos' death on $18^{\text {th }}$ April 1903, Paula von Falkenberg and the children inherited the northernmost parts of the Tüköry estate, which is the present-day municipality of Končanica.

In spring 1904, Paula von Falkenberg decided to build a country house as a new home for her and her three children, which would serve as the managerial centre of their estate. A small forested hill south of Ilova River, with several vineyards on its hilltops and orchards on its slopes, proved to be an idyllic pastoral scene for the new mansion. It was in close proximity of Śplja Lipa village, which had a train station, and the location was not too far from their fishponds, whose building began in 1903. Paula von Falkenberg consulted art historian Jenő Radisics, director of the Museum of Applied Arts in Budapest, who referred her to Ernő Foerk and Gyula Sándy, two already established young architects he deemed suitable for such a task [8]. Moreover, that year, another design by Foerk and Sándy saw its realisation in Croatia - the palace of the Post and Telegraph Administration Office in Zagreb [9].

Evoking the recognisable elements of castellated architecture, Foerk and Sándy designed a mansion that was neither a villa nor a hunting lodge, but a genuine manor house in which the family resided both in winter and summer months [11]. The first preliminary design from 1904, drawn by Ernő Foerk, was titled Studie zu einem Herrenhaus (Study for a Manor House), and it depicted the ground floor plan together with the north elevation of the future mansion (Figure 2). Sándy's journal reveals that the layout was devised by Sándy, while Foerk designed the architectural appearance of the façades [8]. 


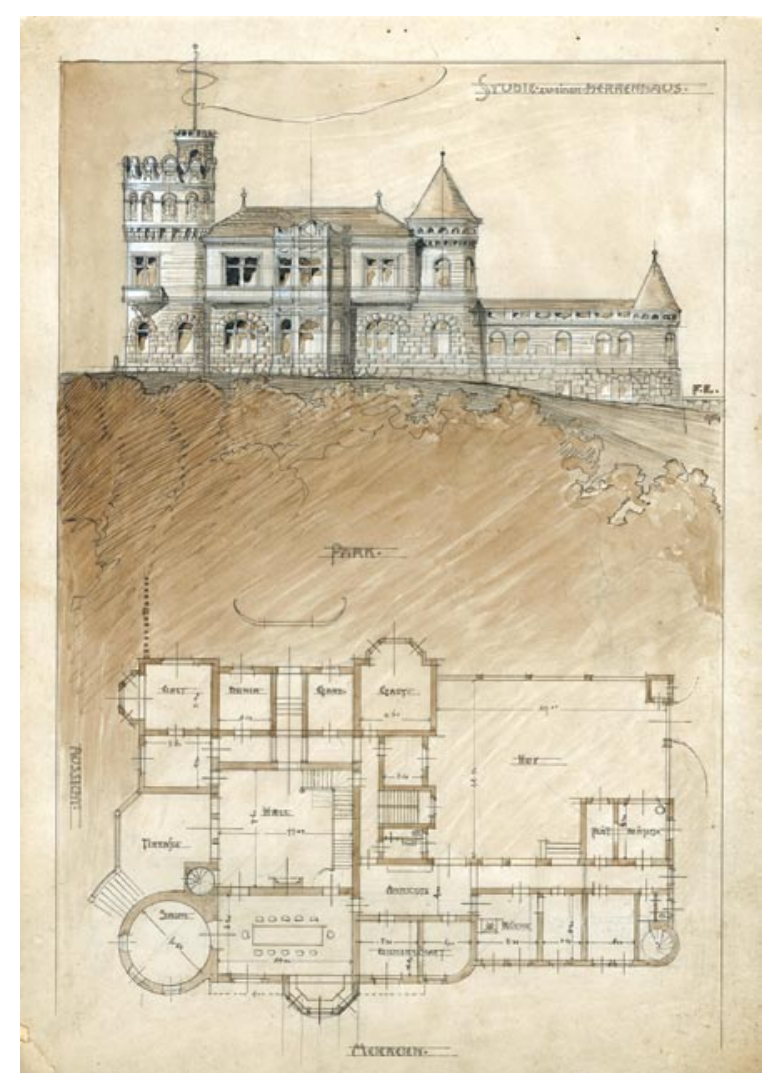

Figure 2. Preliminary design for Tüköry Mansion / „Study for a Manor House” (1904), ground-floor plan and north elevation [10]

The architects conceived the mansion as a Neo-Romanesque burgstyle manor [12]. Its overall volume is divided into two main parts: the two-storey-high representative dwelling of with a square layout, and the servants' wing enclosing a yard on the west side of the mansion. The main entrance is placed on the south façade, overlooking the vehicle drive and park. The central part of the layout is a great hall, 9,5 metres wide and 9 metres high, and capped with a barrel vault made of reinforced concrete. Originally, its main feature was a grand oak staircase, which no longer exists, that led to one of the two galleries overlooking the great hall from the upper storey. The galleries were integral parts of a corridor that encompassed the great hall and served as horizontal communication between the sleeping quarters and other private rooms. On the ground-floor level, encircling the great hall were salons, a large dining room, a children's dining room and a smoking lounge [13]. A guest apartment and a guest room flanked the main entrance from both sides, and the servants' corridor extends along the west wall of the great hall, leading to the servants' wing.

The concept of the layout is clearly visible in the design of the elevations through the distinction in height between the representative part and servants' wing, as well as in the position of the great hall. However, the principal architectural element of the silhouette is not the elaborate mansard roof covering the representative part with the great hall, but a large castellated tower positioned on the north-east corner of Tüköry Mansion. 
The tower contains an additional room on its third storey, and a terrace on the top, where the battlement serves as a fence. The terrace is approached via a spiral-staircase bartizan.

The preliminary design of the tower in Dioš is (with some minor alterations) identical to the corner tower of the General Post Office on Krisztina Boulevard in Budapest, designed by Gyula Sándy in 1920s [14, 15]. In the final realisation of the Tüköry Mansion, however, the tower was modelled after the roccas of Lombardy, with simple rectangular-shaped merlons and red brick, a signature element of Foerk and Sándy's façades. The tower resembles the late-mediaeval architecture of northern Italy, featuring ornaments very similar to those on the façades of the Mediaeval Castle (Borgo Medioevale) in Turin, which was built for the General Italian Exposition in 1884 and which doubtlessly inspired numerous other Foerk's and Sándy's designs. In addition, the entire roof composition is enriched with several turrets, which provide the country house with a startling silhouette. It is hardly surprising that leading Hungarian architecture historians tend to classify Sándy and Foerk's stylistic inclinations under the "castellated provincial Rennaisance of Upper Hungary" (Hun. felvidéki pártázatos reneszánsz) [16].

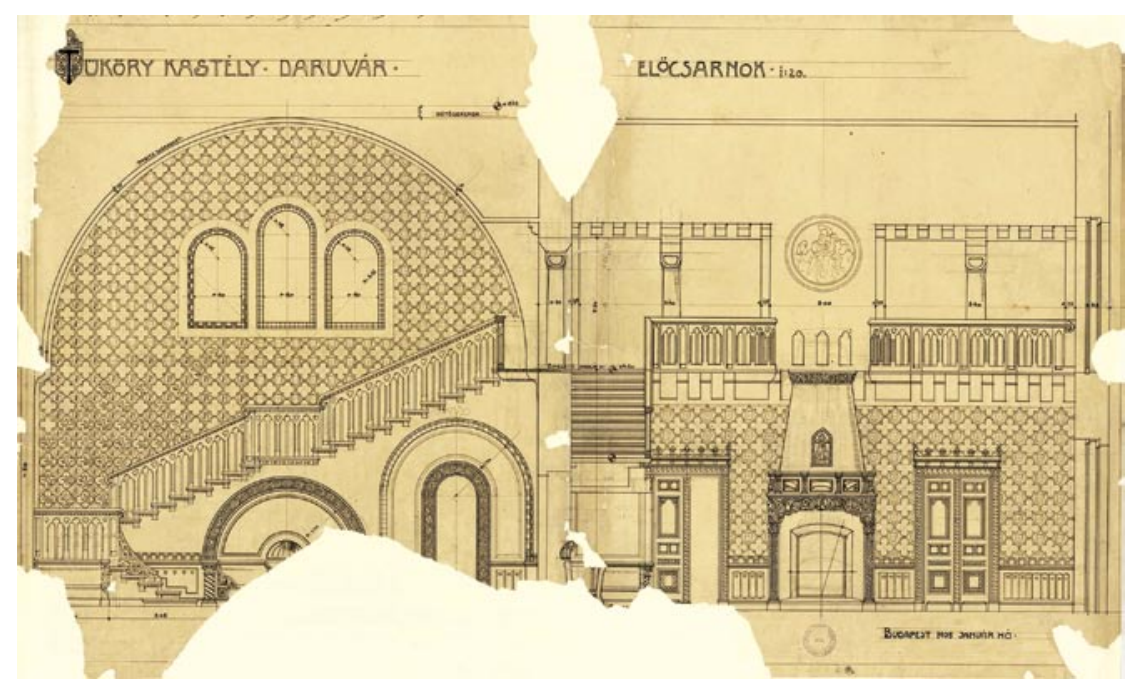

Figure 3. Detailed design for the great hall of Tüköry Mansion (January 1905), the west and north walls [17]

\section{THE HEARTH OF THE MANSION}

During the building of Tüköry Mansion, the architects and the investor devoted great attention to architectural and artistic details of the interior. With the construction of walls was already in progress, Foerk and Sándy worked on detailed drawings of the interior, specifically the great hall, designed as a central room of the mansion. The great hall was conceived as a sala baronale - originally a large and rectangular room that served as a semi-public administrative centre of local life and estate, a common feature of northern Italian stately architecture. It is also reminiscent of a closed central courtyard (cortille), which was another common feature of northern Italian castelli. In Tüköry Mansion the great hall was the most representative room and a central hub leading to both representative and service tracts. Naturally, this warranted special architectural and artistic treatment, and great attention was directed even to the smallest of details. 
A substantial architectural element of the great hall was the grand, representative oak staircase. It was situated along the west wall of the room, and led to one of the second-storey galleries. The staircase was composed of three flights of stairs: two flights descending along the west wall in continuation, axially interrupted by a landing, with a winder on the lower end leading to a third, lavishly decorated bottom flight of stairs. The bottom flight is connected to the higher flights with a landing that contained a bench on its outer side facing the room. Under the staircase were two barrel-vaulted niches - a lower central niche furnished with a pair of decorative benches identical to the one at the bottom of the stairs, and a higher niche with a small door leading to the servants' wing. The decoration of the railing, articulated with a row of openings reminiscent of Gothic tracery, was identical to the railing on the balconies of the second-storey galleries that survived to this day.

In January 1905, Foerk and Sándy made a detailed design of the north and west wall in the great hall, in scale 1:20 (Figure 3). In the central axis of the northern wall, between the two gallery balconies, the drawing shows a large decorative fireplace in the style of marble fireplaces of the Carrara region in Italy.

During the designing process, Paula von Falkenberg informed the architects that she had been offered a "white marble fireplace originating from a mediaeval Italian castle" by Miksa Schmidt, well-known furniture designer and seller of the antiquities in Budapest. Before completing the purchase, she asked that Foerk and Sándy come to see the fireplace in Schmidt's workshop, upon which they became aware that the fireplace was in reality a guileful copy by a very crafty stonemason. Not wanting to risk a lawsuit, the architects agreed between them not to expose their doubts to Paula von Falkenberg, especially as the fireplace fit perfectly in their design. Sándy and Foerk's doubts were confirmed several years later, when an identical fireplace was sold by Miksa Schmidt to the wife of Leo Lánczy, Director of the Hungarian Commercial Bank [18]. Today, the fragments of the fireplace from the Tüköry Mansion are kept in the Janković Manor in Daruvar, as part of the town museum collection.
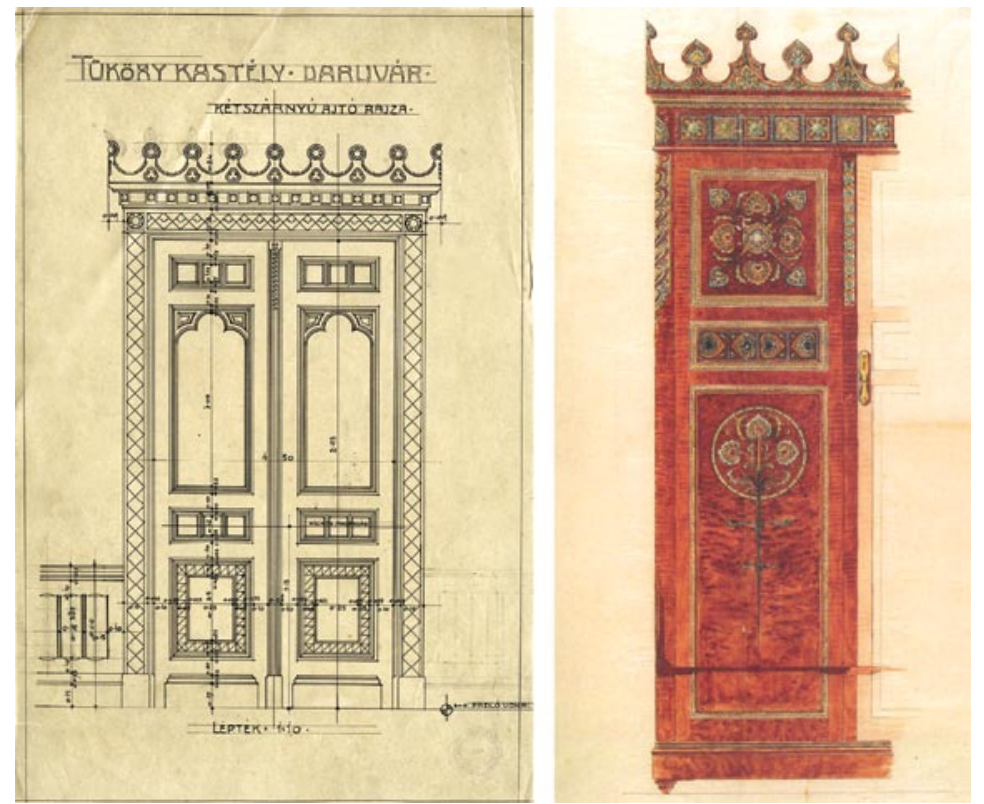

Figure 4 a) Detailed design for the double door in the great hall of Tüköry Mansion (presumably 1905) [19]; b) Ernő Foerk's design for a wardrobe in the Hungarian Parliament building (around 1900) [20] 
Among the project documentation of the wooden elements, there is a detailed drawing of one of the double oak doors in the great hall in scale 1:10, which also contains the design for parapet-high wall panels (Figure 4.a). The doors of the great hall are adorned with stylized foliate and geometric ornaments. The frame with a brattishing on the top is very similar to Ernő Foerk's design for a wardrobe in the Hungarian Parliament, which he drew around 1900 when he worked in Imre Steindl's studio (Figure 4.b).

A detailed design for the great hall by Foerk and Sándy dating from January 1905 includes the first preliminary concept for wall paintings. The paintings were envisioned as alternating patterns of crests and quatrefoils with zoomorphic motifs. Another detailed drawing, published by the architects in 1905 [21], shows the north wall of the room with two alternating stripes - one with animal motifs in squared frames and the other with a continuing foliate acanthus motif. As the paintings on the north and south walls are partially preserved to this day, we know that they were eventually realised as a sequence of four alternating decorative stripes: the first with the continuing Romanesque interlace, the second with the labarum symbol in squared frames, the third with a continuing motif of grapes and vines, and the fourth consisting of a cross with four roses in squared frames. An additional continuing interlaced stripe follows the semicircular outline of the barrel vault. The north and south walls, on the other hand, contained a pattern similar to that on the detailed drawing from January 1905. The pattern contained two variants of alternating lily shapes and quatrefoil frames with four different zoomorphic motifs: a lion, a pigeon, a gryphon, and a crested bird. There are two archival photographs that depict the original state of wall paintings in the great hall (Figure 5), but their exact dimensions and colours were determined by restoration probes.
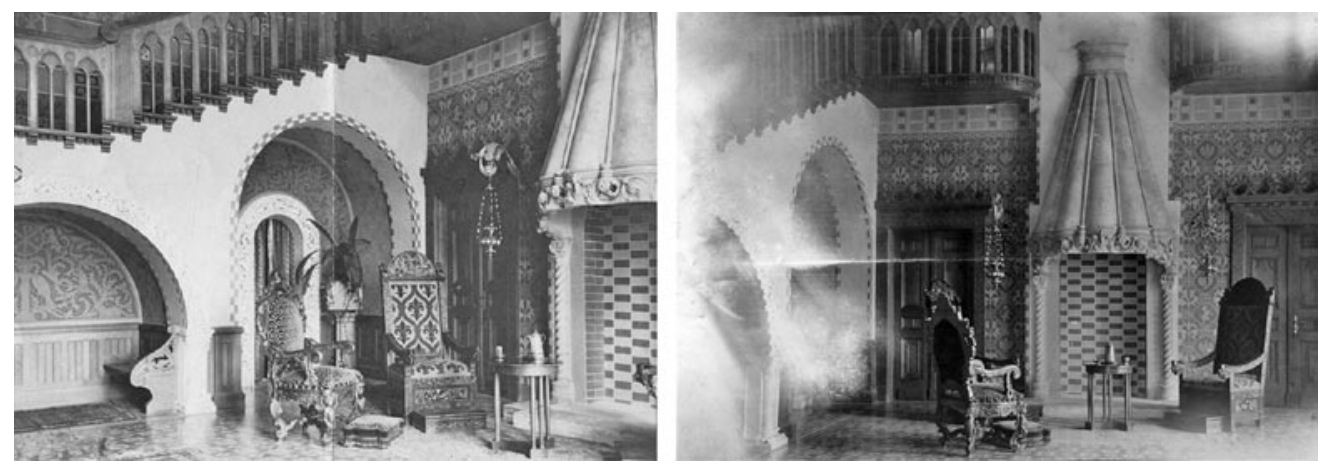

Figure 5. The original state of the great hall in Tüköry Mansion (around 1905) [22]

Several additional motifs were preserved at the base of the barrel vault on the south wall of the hall. The base of the vault is (only decoratively) placed on simple corbels, upon which there is a interlaced pattern with a decorative frieze - a sequence of alternating red and blue crest-like frames. Blue frames are reserved for motifs depicting an acanthus plant in a vase, and red frames contain individually designed scenes from the mediaeval bestiary. The aesthetic and formal vocabulary of the animal motifs is noticeably similar to the motifs of several northern Italian well heads (also fonts or pozzos) dating from the $8^{\text {th }}$ to $12^{\text {th }}$ century, acquired by the Museum of Fine Arts in Budapest in the 1880s (Figure 6). What is more, motifs similar to those on the fonts in the Museum can be found on the decorative plastic of the great hall - the built-in frames outlining the opening of the lower staircase niche (present in the mansion today), and around the servants' door in the higher niche (fragments found in Daruvar and Bjelovar town museums). The bill for the stonemasonry work was sent in August 1905, and signed by Gyula Král from Budapest [23]. 

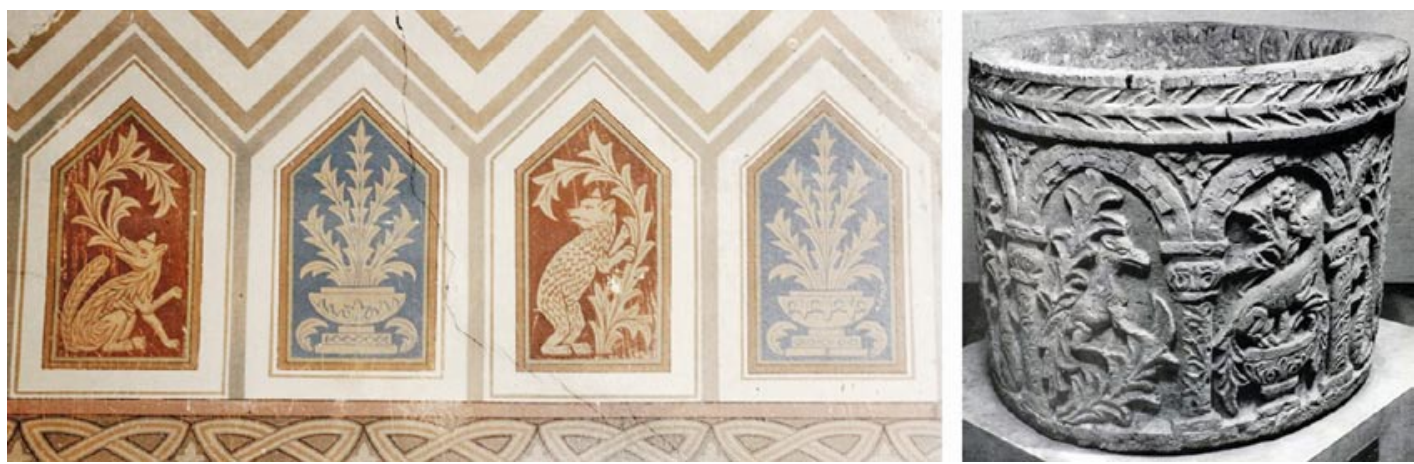

Figure 6 a) Alternating red and blue crest-like frames with animal and plant motifs at the base of the barrel vault in Tüköry Mansion [24]; b) a mediaeval

font at the Museum of Fine Arts in Budapest [25]

The east wall of the room, with doors to the terrace, also has a central architectural element - a large tripartite lunette formed as a thermal (Diocletian) window. In 1905 the lunette was artistically enriched with a stained-glass work depicting St Michael the Archangel battling Satan (depicted as a dragon), which is today a unique example of such representation in Croatian secular architecture. Visually, the motif of the dragon is analogous to the one on the capital of the Votive Church in Szeged (Frigyes Schulek and Ernö Foerk, 1913-1932) which was designed by István Tóth and carved by Béla Seenger [26]. However, the stained-glass window in Dioš shows characteristics of the work of Imre Zsellér, who was mentored by Miksa Róth and who had at that time started his own practice in Thököly út, not far from the technical college where Foerk taught. Besides, in his work for Gyula Petrovácz (with whom Ernő Foerk collaborated in 1907-11) in the years that followed, Zsellér made several other comparable stained-glass windows depicting St Michael fighting the dragon.

Following exhaustive research of archival documentation, combined with results of terrain research of the mansion carried out in July 2018, it was possible to reconstruct the original design of the architectural plastic and the wall paintings of the great hall with high precision (Figure 7). All the factors of identity and artistic influences are known - from the historic forms that evoke mediaeval Lombardy, to specific materials and decorations influenced by the Arts $\&$ Crafts and Art Nouveau. 

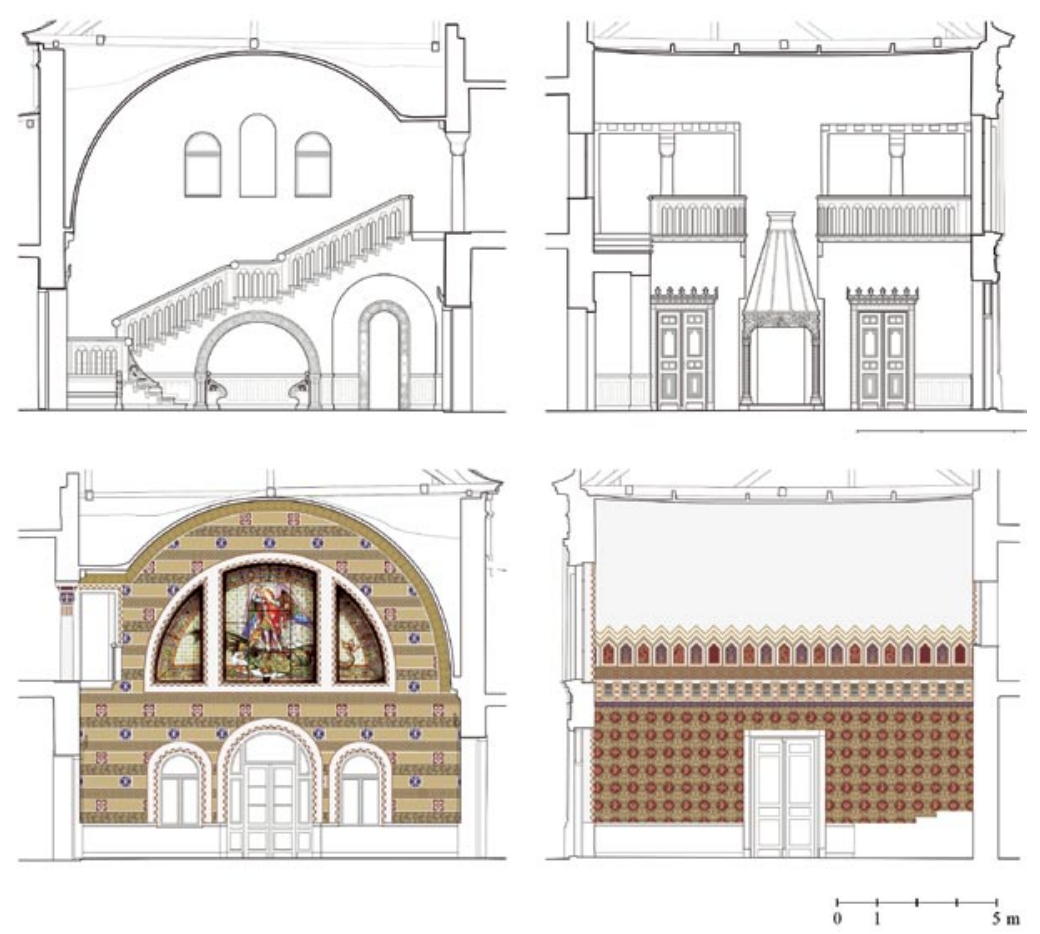

Figure 7. The reconstructed original state of the great hall in Tüköry Mansion: architectural and s culptural elements of the west and north walls (up) and wall paintings with the stained-glass window on the east and south walls (down) [3]

\section{CONTEXTUAL DISINTEGRATION OF ARCHITECTURAL NARRATIVE}

The untouched nature of the location called for such a country house where the surrounding environment would become inherent to its architectural concept. For that reason, one of the most important compositional elements of Tüköry Mansion is its eastern terrace (Figure 8). It is designed as an exterior extension of the great hall which opens toward the surrounding park and forest. Furthermore, it also contains something of the stylistic narrative present in the great hall, albeit with lesser intensity. As most Italian cortilles, it had a water well. The terrace fence was adorned with a sculpture of a "Venetian" lion placed on a pair of Byzantium-styled columns [8]. Paula von Falkenberg even applied several archaeological artefacts on the outer wall of the corner tower (aforementioned rocca). Unfortunately, only the lion sculpture still exists today, preserved in the spa complex of Daruvar.

For Paula von Falkenberg, the building of Tüköry Mansion was a process of rewriting her family's history. By naming the location Diósszentpál, she dedicated the place to her prematurely deceased son Pál. Furthermore, a plate installed on the façade read: "God bless this house built by the widow of Alajos Tüköry, born Paula Falkenberg, in memory of her husband in 1904" [27].

Ernő Foerk and Gyula Sándy also planned to build a chapel mausoleum in the surrounding park, but the design never saw its realisation [28]. The fable-like motifs of decorative elements resonated with Paula von Falkenberg's desired family narrative. However, a year after the project was finished, she remarried to Gyula Pekár and soon sold the mansion, together with the surrounding estates. 
After the end of the First World War, the turbulent national, social, and political situation on the territory of the former empire left the majority of the country houses to oblivion and decay, which almost completely erased the cultural presence of the Tüköry family from the area of Daruvar and Končanica. From the War onward, the visual and stylistic elements of the Tüköry Mansion so craftily incorporated by Ernő Foerk and Gyula Sándy, as well as the archaeological artefacts carefully curated by Paula von Falkenberg, were inopportunely emptied of meaning and significance. Only at the end of the twentieth century has the mansion started to evoke public interest and awareness of its significance, calling for exhaustive conservation research in order to reinstate the knowledge of its history.
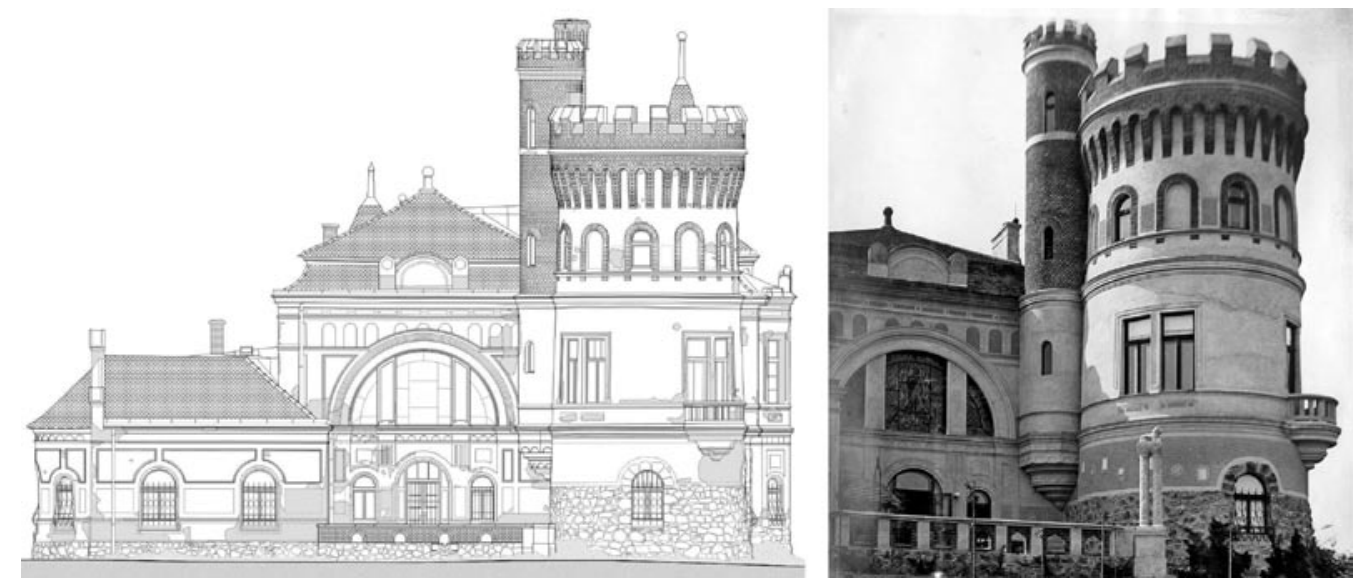

Figure 8. Tüköry Mansion, east elevation with the terrace: a) detailed architectural survey of the current state [29]; b) photograph of the original state [22]

\section{CONCLUSION}

As a result of oblivion and continuous (if inadequate) use, Tüköry Mansion preserved most of its initial overall architectural appearance. As one of the youngest Slavonian country houses, its historical data is largely preserved and can serve to present some of its original historical layers. Pending additional professional deliberation upon sufficient models of architectural presentation and revitalisation, Tüköry Mansion awaits a new purpose, suitable for the presentday economy and appropriate for the local community. As a first step towards that goal, this paper showcases the in-depth research of architectural and cultural history of the mansion, which is essential in recognising and implementing suitable and efficient models of active use [30]. It presents the initial comprehensive architectural and stylistic genealogy, which serves as a basis for further reconstruction and restoration endeavours.

The conclusions are based upon activities carried out by the Croatian Conservation Institute in 2017 and 2018. The detailed architectural survey and the conservation-restoration study are a result of a close collaborative effort of Croatian and Hungarian institutions and researchers, which will hopefully continue in realisation phases that are yet to come. 


\section{ACKNOWLEDGEMENTS}

The first results of the author's research of Tüköry Mansion were presented in his master thesis "Revitalisation of Tüköry Mansion in Dioš: A Conceptual Design of the Village and Its Country House Complex" at the Univesity of Zagreb, Faculty of Architecture, in 2016 (mentored by Prof. Mladen Obad Šćitaroci, Ph.D., F.C.A.). However, a larger part of the research was conducted at the Croatian Conservation Institute in Zagreb in 2018. The author is immensely thankful to colleagues Borka Milković and Bernarda Ratančić from the Institute for their guidance, contribution and consultation in the preparation of the study. The author also cordially thanks Eszter Baldavári from the Hungarian Museum of Architecture in Budapest for kind support in this research.

\section{REFERENCES}

[1] A Gesamtkunstwerk is a total work of art which embraces many art forms. It was the aesthetic ideal of the nineteenth and early twentieth centuries, particularly in the Arts and Crafts tendencies of the period. In architecture, it includes architectural design of a building, together with designs for sculptures, paintworks, accessories, furnishings, and landscape.

[2] A postcard from the author's archive.

[3] Dundović, B., Milković, B., Ratančić, B., Končanica, Dvorac Dioš (Marijin dvor): Elaborat konzervatorsko-restauratorskih istraživanja, Zagreb: Hrvatski restauratorski zavod, 2018.

[4] Szabo, Gu., Iz prošlosti Daruvara i okolice, Narodna starina, Volume 11 (1932), No 28, 79-98.

[5] Dundović, B., Obad Šćitaroci, M., Bojanić Obad Šćitaroci, B., Revitalisation of Country Houses Along the Route 'Tracing the Steps of Counts Jankovich': Guidelines for Nodes of Functional Intensities, Cultural HeritagePossibilities for Spatial and Economic Development [ed. Obad Šćitaroci, M.], Zagreb: University of Zagreb, Faculty of Architecture, 2015, pp. 114-119.

[6] Simkó, G., Túl a Dráván, Nagy-Károly és vidéke, Volume 16 (1900), No 28, 1-2.

[7] Karaula, Ž., Prilog za poznavanje povijesti vlastelinske obitelji Tüköry de Algyest u Daruvaru tijekom druge polovice 19. i početkom 20. stoljeća, Zbornik Janković, Volume 2, 76-92.

[8] Sándy, Gy., Hogyan lettem és hogyan voltam én templom-építő, -tervező és müvezető építész?, Lapis angularis VI (Források a Magyar Épitészeti Múzeum gyüjteményéből) [eds. Fehérvári, Z., Hadik, A., Prakfalvi, E., Zászkaliczky, Zs.], Budapest: Magyar Építészeti Múzeum, 2005, p. 88.

[9] Dundović, B., The Palace of the Post and Telegraph Administration Office in Jurišićeva Street, Zagreb; Architectural and Stylistic Features, Prostor, Volume 24 (2016), No 1, 14-31.

[10] Hungarian Museum of Architecture, inv. no. 91.09.5.1.

[11] Foerk, E., SÁNdy, Gy., A Tüköry-kastély Diósszentpálon, A Magyar Mérnök és Épitész Egylet Közlonye, Volume 39 (1905), No 12, 501-505.

[12] Dundović, B., Obad Š́́itaroci, M., Bojanić Obad Šćıtaroci, B., Prolegomenon to the Comparison of Stylistic Features of Hungarian and Croatian Manor Houses in Historicism, Prostor, Volume 20, No 2, 352-367.

[13] Obad Š́́ítaroci, M., Bojanić Obad Šćitaroci, B., Manors and Gardens in Croatia: Slavonia - from Zagreb to Vukovar, Zagreb: Šćitaroci, 1998, pp. 122-125.

[14] Sisa, J., Kastélyépítészet és kastélykultúra Magyarországon: A historizmus kora, Budapest: Vince Kiadó, 2007, p. 270.

[15] Fehérvári, Z., Prakfalvi, E., A budai Postapalota, Ars hungarica, Volume 41 (2015), No 1, $48-63$.

[16] Gerle, J., Kovács, A., Makovecz, I., A századforduló magyar építészete, Budapest: Szépirodalmi Könyvkiadó, 1990.

[17] Hungarian Museum of Architecture, inv. no. 2002.10.10.6.

[18] Sándy, Gy., work cited in note 8 above, p. 89.

[19] Hungarian Museum of Architecture, inv. no. 2002.10.10.7.

[20] SisA, J., Steindl Imre (Az építészet mesterei), Budapest: Holnap Kiado, 2005, p. 145. 
[21] Foerk, E., Sándy, Gy., work cited in note 10 above, p. 504.

[22] Hungarian Museum of Architecture, Gyula Sándy’s bequest, Tüköry Mansion, interior photographs of the great hall.

[23] Hungarian Museum of Architecture, Gyula Sándy’s bequest, box no. 1, folder no. 86.

[24] Photograph taken by the author in 2017.

[25] Museum of Fine Arts, Budapest, Collection of Old Sculptures, inv. no. 59.13.

[26] YвL, E., A szegedi Templom-tér épületeinek iparmüvészeti értékei, Magyar Iparmüvészet, Volume 35 (1932), No 1-2, 8-25.

[27] SchejBal, B., Dvorac Dioš ili Marijin dvor, Hrvatske šume, Volume 9 (2005), No 108, 36-37.

[28] Foerk, E., SÁndy, Gy., work cited in note 10 above, p. 505.

[29] VeKTRA D.o.o., Dioš, Dvorac Dioš: Arhitektonska snimka postojećeg stanja, Varaždin: Vektra, 2018.

[30] Dundović, B., Obad Šćitaroci, M., Sisa, J., Revitalisation Models for Central European Country Houses, Cultural Urban Heritage: Development, Learning and Landscape Strategies [eds. Obad Šćitaroci, M., Bojanić Obad Šćitaroci, B., Mrđa, A.], Cham: Springer, 2019, pp. 443-455. 